Article

\title{
The Effects of Fineness and TEA-Based Chemical Admixture on Early Strength Development of Concrete in Construction Site Applications
}

\author{
Taegyu Lee ${ }^{1,+} \oplus$, Jaehyun Lee ${ }^{1,+} \mathbb{C}$, Hyeonggil Choi ${ }^{2, *}$ and Dong-Eun Lee ${ }^{2}$ \\ 1 Technology Research \& Development Institute, Daelim Industrial, Jongno-Gu, Seoul 03152, Korea; \\ ninga777@naver.com (T.L.); archi0528@daum.net (J.L.) \\ 2 School of Architecture and Civil Engineering, Kyungpook National University, 80 Daehakro, Bukgu, \\ Daegu 41566, Korea; dolee@knu.ac.kr \\ * Correspondence: hgchoi@knu.ac.kr; Tel.: +82-53-950-5596 \\ + These authors contributed equally to this work as first author.
}

Received: 31 March 2020; Accepted: 23 April 2020; Published: 26 April 2020

\begin{abstract}
This study examines effects of cement fineness and chemical admixtures of early strength agents on the early strength development of concrete. Three cement types were selected, namely ASTM type-I ordinary Portland cement (OPC), fineness ordinary Portland cement (FOPC), and ASTM type-III early Portland cement (EPC), and the mixing proportions of concrete were set by adding a triethanolamine-based chemical admixture to FOPC. The evaluation items considered in this study included raw material analysis, compressive strength, and maturity (D.h). The time required for the development of concrete strength of $5 \mathrm{MPa}$ in the three cement types was estimated and compared. The results revealed that using FOPC enhances the strength development of concrete owing to its higher fineness and $\mathrm{SO}_{3}$ content compared to OPC. In addition, it has been observed that using both FOPC and TCA yields a similar performance to that observed using EPC, in light of the improved early strength development at low temperatures.
\end{abstract}

Keywords: cement fineness; fine ordinary Portland cement; TEA-based chemical admixture; concrete strength; early strength development

\section{Introduction}

Concrete forms a structural matrix by combining cement, water, fine aggregate, coarse aggregate, and admixture. The strength of concrete is developed by the homogeneous bonding force of each material, and the primary influential factor of the strength development is cement. Cement is condensed and cured as it stabilizes while releasing heat energy through its hydration reaction with water [1-3]. Concrete features excellent compressive strength development, while facilitating easy attachment of reinforcement bars. In addition, the strong alkali performance of concrete ensures durability by limiting the corrosion of reinforcing bars. In addition, concrete is easily available for purchase and use. Additionally, the use of concrete is favored in construction sites owing to its excellent workability prior to condensation and hardening. Concrete hardens and develops strength when its fluidity decreases. This is an important target of quality control, as a critical path for construction sites [4].

Moreover, the most economical and efficient process control is pursued in construction sites, which is closely related to the strength development period of concrete. Concrete remains in formwork until its strength development achieves sufficient structural stability, and each country has different criteria for compressive strength. These include the minimum time [5-7] and minimum strength $[8,9]$ required for formwork removal. Concrete strength of $5 \mathrm{MPa}$ or higher is considered a minimum strength criterion to ensure structural stability. 
As concrete is significantly affected by temperature during the hydration process of cement, its strength development tends to decrease at low temperatures. There are cases when strength development becomes impossible if the hydration reaction stops for a certain period. Considering these characteristics, many studies have reported on the early strength development of concrete at various curing temperatures [10-12].

Ordinary Portland cement (OPC) has been primarily used as a binder because it exhibits stable strength development at temperatures of $15^{\circ} \mathrm{C}$ or higher. Its strength development, however, tends to be delayed at low temperatures. Consequently, cases in which strength development was examined using early strength cement and early strength chemical admixture to improve the strength development of cement through hydration have been continuously reported [13-18].

Frigione et al. [19-21] reported that early strength development can be achieved through the rapid reaction between cement and water by increasing the fineness of the cement.

It has been observed that the hydration degree of cement increases with a reduction in its particle size. Klein and Metha [22] presented the possibility of early strength development for the $\mathrm{CaO}-\mathrm{Al}_{2} \mathrm{O}_{3}-\mathrm{SO}_{3}$ system due to the generation of various hydrates according to the $\mathrm{Al}_{2} \mathrm{O}_{3} / \mathrm{SO}_{3}$ and $\mathrm{CaO} / \mathrm{SO}_{3}$ molar ratios. Lee et al. $[23,24]$ examined the effect of fineness and $\mathrm{SO}_{3}$ content on the strength development of fine ordinary Portland cement (FOPC) at early ages.

It has been observed that commercialized fine ordinary Portland cement (FOPC), which improved the $\mathrm{OPC}$ powder and $\mathrm{SO}_{3}$ contents, demonstrates enhanced early strength development in the $13-15^{\circ} \mathrm{C}$ temperature range. ASTM C150 [25] specifies 3.1\% as the optimum $\mathrm{SO}_{3}$ concentration in cement to ensure sufficient early strength of OPC.

Hewlett et al. [26-28] proposed the use of a high-performance superplasticizer added to an early accelerating agent to improve early strength of OPC. Additionally, they presented results pertaining to early strength development of triethanolamine (TEA)-based chemical admixtures, which facilitates acceleration of the hydration of tricalcium aluminate (C3A), thereby contributing to OPC hydration.

However, these extant studies mostly dealt with mortar-based materials and lacked consideration of quality control aspects, such as those pertaining to the economic efficiency of mixing, batch plant productivity, and in-field workability during application in construction sites. In addition, it is necessary to examine the early strength of various commercialized cements in order to ensure consistent quality in mass production and optimized mix design in construction sites.

In this study, various binders, such as OPC, early Portland cement (EPC), and FOPC, were selected based on the $\mathrm{C} 24$ (characteristic value of concrete $24 \mathrm{MPa}$ ) concrete mix, which is produced in ready-mixed concrete factories. Their influence on early strength development at different curing temperatures was examined. In addition, polycarboxylate (PC)-based superplasticizers with early strength agents were added and their influence on strength development was analyzed.

\section{Materials and Methods}

\subsection{Materials}

Table 1 shows the chemical compositions of the used binders by X-ray fluorescence (XRF, Axios PW 4400, Malvern Panalytical, Seongnam-si, Korea) analysis. The concrete binders ASTM type-I OPC with density equal to $3150 \mathrm{~kg} / \mathrm{m}^{3}$ and fineness of $330 \mathrm{~m}^{2} / \mathrm{kg}$, FOPC with density equal to $3130 \mathrm{~kg} / \mathrm{m}^{3}$ and fineness of $380 \mathrm{~m}^{2} / \mathrm{kg}$, and ASTM type-III EPC with density equal to $3160 \mathrm{~kg} / \mathrm{m}^{3}$ and fineness of $488 \mathrm{~m}^{2} / \mathrm{kg}$ were considered in this study. 
Table 1. Chemical composition of binders used in this study, as observed via X-ray fluorescence (XRF) analysis.

\begin{tabular}{cccccccccc}
\hline \multirow{2}{*}{ Materials } & $\mathbf{8}$ Chemical Compositions (\%) & \multirow{2}{*}{ L.O.I. $^{\mathbf{4}}$} \\
\cline { 2 - 9 } & $\mathbf{C a O}$ & $\mathbf{S i O}_{\mathbf{2}}$ & $\mathbf{A l}_{\mathbf{2}} \mathbf{O}_{\mathbf{3}}$ & $\mathbf{M g O}$ & $\mathbf{F e}_{\mathbf{2}} \mathbf{O}_{\mathbf{3}}$ & $\mathbf{S O}_{\mathbf{3}}$ & $\mathbf{K}_{\mathbf{2}} \mathbf{O}$ & Others & \\
\hline $\mathrm{OPC}^{1}$ & 61.44 & 20.33 & 4.72 & 2.95 & 3.42 & 2.9 & 0.95 & 1.62 & 1.67 \\
$\mathrm{FOPC}^{2}$ & 60.34 & 19.82 & 4.85 & 3.83 & 3.30 & 3.13 & 1.08 & 0.63 & 3.02 \\
$\mathrm{EPC}^{3}$ & 61.00 & 19.22 & 4.51 & 4.14 & 3.35 & 3.73 & 1.04 & 0.19 & 2.82 \\
\hline
\end{tabular}

${ }^{1}$ OPC: ordinary Portland cement; ${ }^{2}$ FOPC: fine ordinary Portland cement; ${ }^{3}$ EPC: early Portland cement; ${ }^{4}$ L.O.I.: loss on ignition.

Figure 1 shows the gradation sieve analysis curves of the fine and coarse aggregates used. As for fine aggregate, washed sea sand (fineness: 2.01 , density: $2600 \mathrm{~kg} / \mathrm{m}^{3}$, absorption: $0.79 \%$ ) and crushed sand (fineness: 3.29 , density: $2570 \mathrm{~kg} / \mathrm{m}^{3}$, absorption: $0.87 \%$ ) were mixed and used. The fineness of the mixed fine aggregate was 2.84 . For the coarse aggregate, crushed granite aggregate (size: $25 \mathrm{~mm}$, density: $2600 \mathrm{~kg} / \mathrm{m}^{3}$, absorption: $0.76 \%$ ) was used.

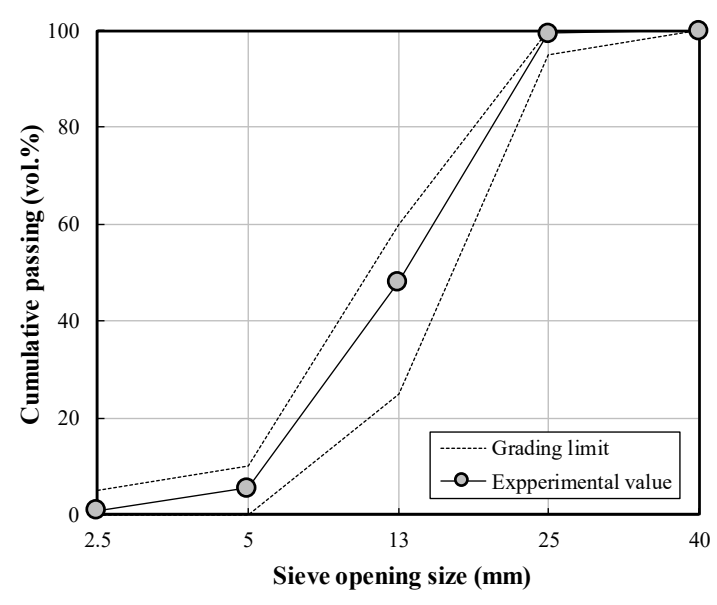

(a)

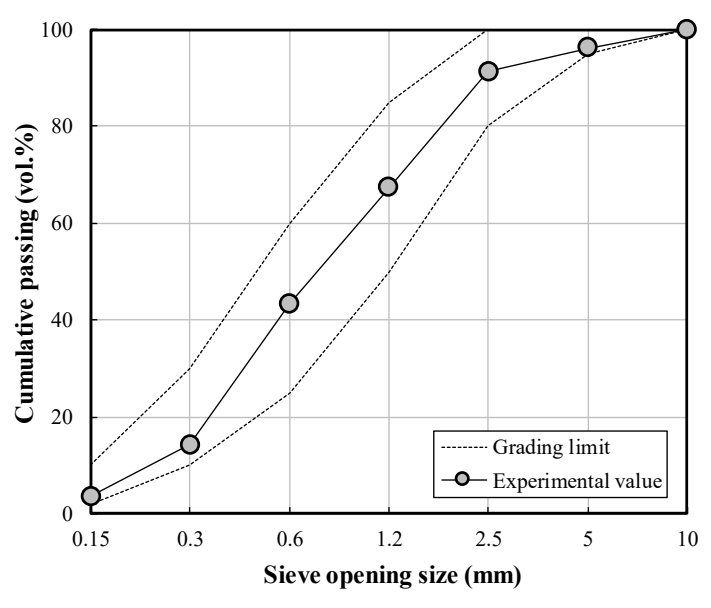

(b)

Figure 1. Gradation sieve analysis curves of aggregates used: (a) coarse aggregates; (b) fine aggregates.

As for chemical admixtures, a PC-based admixture (polycarboxylic acid group) and a PC-based admixture with added sodium nitrate $\left(\mathrm{NaNO}_{3}\right)$ and sodium sulfate $\left(\mathrm{Na}_{2} \mathrm{SO}_{4}\right)$ based on triethanolamine (TEA) (hereafter, TEA-based chemical admixture) were used.

\subsection{Experimental Plan and Mix Proportions}

Table 2 lists the experimental plan followed in this study. As for the concrete strength, C24, which is most commonly used in construction sites, was selected. The water/cement (W/C) ratio was fixed at 0.50 , the unit water content was $165 \mathrm{~kg} / \mathrm{m}^{3}$, and the total amount of cement was $330 \mathrm{~kg} / \mathrm{m}^{3}$. As for the types of cement, OPC, FOPC, and EPC were selected. For chemical admixtures, PC-based superplasticizer was used. Additionally, a TEA-based chemical admixture was used for FOPC because it was expected to increase the chemical effect of FOPC (refer to Lee et al. [23,29]). 
Table 2. Experimental plan.

\begin{tabular}{|c|c|c|c|c|c|}
\hline $\mathrm{W} / \mathrm{C}^{1}$ & $\begin{array}{l}\text { Cement } \\
\text { Type }\end{array}$ & $\begin{array}{l}\text { Unit Weight of } \\
\text { Cement }\left(\mathrm{kg} / \mathrm{m}^{3}\right)\end{array}$ & $\begin{array}{l}\text { Chemical } \\
\text { Admixture }\end{array}$ & $\begin{array}{c}\text { Curing Temperature } \\
\left({ }^{\circ} \mathrm{C}\right)\end{array}$ & Evaluation Item \\
\hline 0.50 & $\begin{array}{l}\text { OPC } \\
\text { FOPC } \\
\text { FOPC } \\
\text { EPC }\end{array}$ & $\begin{array}{l}330 \\
330 \\
330 \\
330\end{array}$ & $\begin{array}{l}\mathrm{PC}^{2} \\
\mathrm{PC}^{3} \\
\mathrm{TCA}^{3} \\
\mathrm{PC}\end{array}$ & $\begin{array}{c}\text { Outdoor }{ }^{4} \\
\text { Chamber }\left(13^{\circ} \mathrm{C}\right) \\
\text { Cast in Place }{ }^{5}\end{array}$ & $\begin{array}{c}\text { Slump }(\mathrm{mm}) \\
\text { Air contents }(\%) \\
\text { Compressive strength } \\
\text { - Cylinder Mold(Ø100 × 200) } \\
-18 \mathrm{~h}, 24 \mathrm{~h}, 72 \mathrm{~h} \\
\text { Maturity }(\mathrm{D} \cdot \mathrm{h})\end{array}$ \\
\hline
\end{tabular}

${ }^{1}$ W/C: water/cement ratio; ${ }^{2}$ PC: polycarboxylate; ${ }^{3}$ TCA (TEA-based chemical admixture); ${ }^{4}$ Outdoor: average temperature $=12{ }^{\circ} \mathrm{C} ;{ }^{5}$ Cast in place (embedded specimens into the slab at curing the outdoor).

To establish concrete curing temperatures, the outdoor (average temperature $=12{ }^{\circ} \mathrm{C}$ ), chamber $\left(13^{\circ} \mathrm{C}\right)$, and cast-in-place (slab-embedded specimens for outdoor curing) conditions were set as illustrated in Figure 2. The compressive strength and maturity (D.h) were measured as evaluation items. Finally, the $5 \mathrm{MPa}$ development time was estimated.

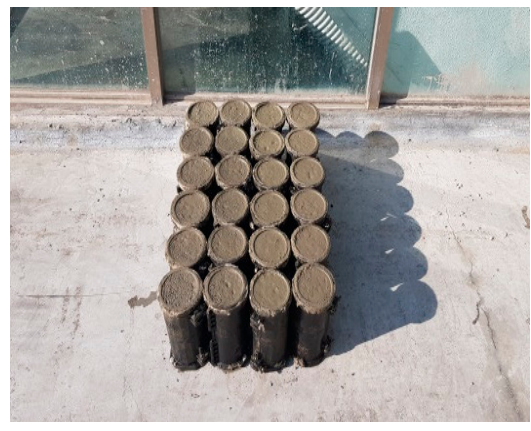

(a)

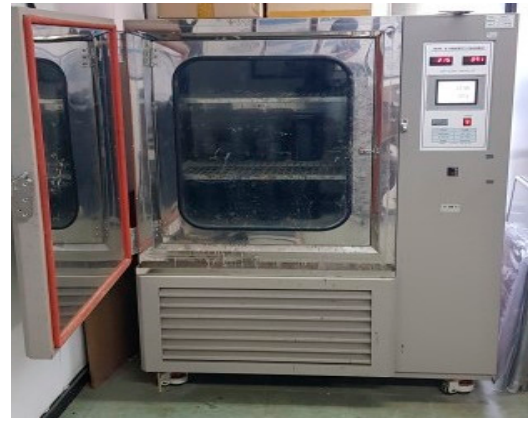

(b)

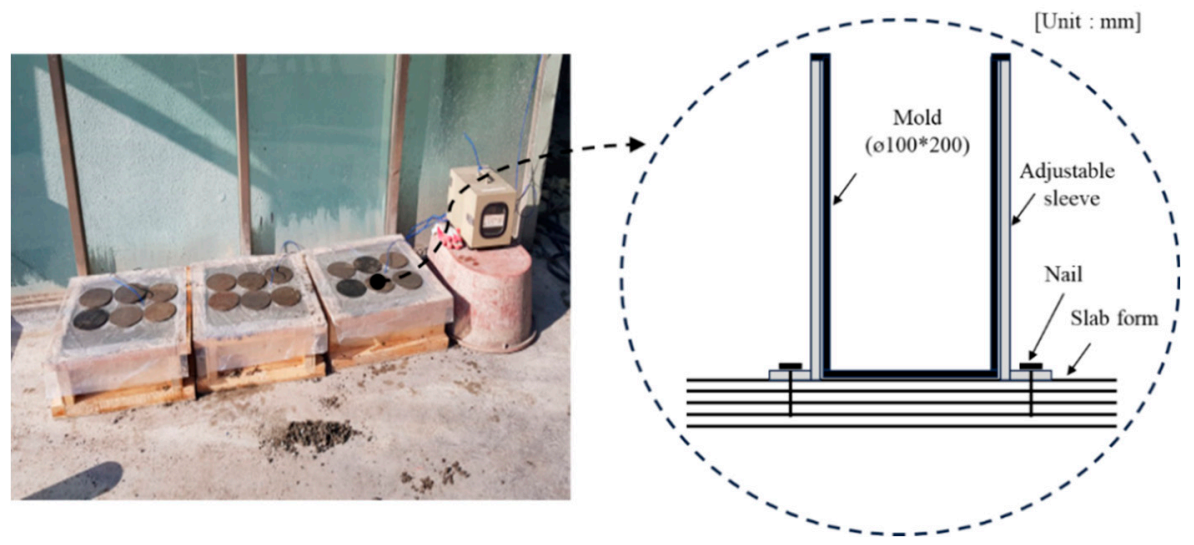

(c)

Figure 2. Photographs of concrete curing methods: (a) air curing; (b) chamber curing; (c) cast-in-place (slab-embedded specimens for outdoor curing).

Table 3 shows the mixing proportions of concrete. The unit water content of concrete was set to $165 \mathrm{~kg} / \mathrm{m}^{3}$, considering the water-reducing ratio of the PC-based admixture. Fine aggregate, washed sea sand, and crushed sand were mixed at a 4:6 ratio. As for the properties of concrete, the slump was set to $180 \pm 25 \mathrm{~mm}$ and the air content to $4.5 \pm 1.5 \%$ to secure sufficient workability for field construction. 
Table 3. Mixing proportions of concrete.

\begin{tabular}{|c|c|c|c|c|c|c|c|c|}
\hline \multirow{2}{*}{ Series } & \multirow{2}{*}{$W / C^{1}$} & \multirow{2}{*}{$\begin{array}{c}S / a^{2} \\
(\%)\end{array}$} & \multicolumn{4}{|c|}{ Unit Weight $\left(\mathrm{kg} / \mathrm{m}^{3}\right)$} & \multirow{2}{*}{$\begin{array}{c}\mathrm{PC}^{7} \\
(\mathrm{~B} \times \%)\end{array}$} & \multirow{2}{*}{$\begin{array}{l}\mathrm{TCA}^{8} \\
(\mathrm{~B} \times \%)\end{array}$} \\
\hline & & & $\mathbf{W}^{3}$ & $C^{4}$ & $S^{5}$ & $\mathrm{G}^{6}$ & & \\
\hline OPC & 0.50 & 50.0 & 165 & 330 & 908 & 919 & 3.30 & \\
\hline FOPC & 0.50 & 50.0 & 165 & 330 & 908 & 919 & 3.30 & \\
\hline FOPC_TCA & 0.50 & 50.0 & 165 & 330 & 908 & 919 & - & 3.30 \\
\hline EPC & 0.50 & 50.0 & 165 & 330 & 908 & 919 & 3.30 & \\
\hline
\end{tabular}

${ }^{1}$ W/C: water/cement; ${ }^{2}$ S/a: sand/aggregates; ${ }^{3} \mathrm{~W}$ : water; ${ }^{4}$ cement; ${ }^{5}$ crushed sand; ${ }^{6}$ G: gravel; ${ }^{7}$ PC: polycarboxylic superplasticizer-based type admixture; ${ }^{8}$ TCA: TEA-based chemical admixture (polycarboxylic superplasticizer-based type with accelerator agent, TEA).

\subsection{Test Methods}

\subsubsection{Properties of Raw Materials}

Table 4 shows the test plan for the properties of the raw materials. In this study, an attempt was made to examine the effects of various types of cement on early strength development. The physical and chemical properties of cement may affect the properties and strength development of concrete. For the raw material analysis, particle size distribution was evaluated in accordance with ASTM C204 [30], scanning electron microscope analysis in accordance with ASTM C1723 [31], XRD in accordance with ASTM C1365 [32], and heat of hydration of cement in accordance with ASTM C1702 [33]. Scanning electron microscopy was performed using the Genesis-2020 microscope (Emcrafts, Gwangju-si, Korea) at $20 \mathrm{kV}$ voltage. X-ray diffraction was performed using X'pert3 Powder PW 3050 (Malvern Panalytical, Seongnam-si, Korea) at $60 \mathrm{kV}$ and $50 \mathrm{~mA}$ voltage and current ratings, respectively. Analysis pertaining to heat of hydration of cement was performed using MMC-511SV6 (6 CH, Tokyo Riko, Tokyo, Japan).

Table 4. Test plan for raw material properties.

\begin{tabular}{cccc}
\hline Items & Materials & Evaluation Items & Test Methods \\
\hline & & Particle size distribution (\%) & ASTM C204 \\
Raw material & OPC & Scanning electron microscope & ASTM C1723 \\
analysis & FOPC & X-ray diffraction & ASTM C1365 \\
& EPC & Heat of hydration & ASTM C1702 \\
\hline
\end{tabular}

\subsubsection{Fresh and Hardened Properties of Concrete}

Table 5 shows the test methods for fresh and hardened properties of concrete. For fresh concrete, the slump was evaluated in accordance with ASTM C143/C143M [34] and the air content was tested in accordance with ASTM C231/C231M-17a [35]. As for the properties of fresh concrete, the initial properties and properties after $60 \mathrm{~min}$ of curing were evaluated considering workability from ready-mixed concrete production to on-site pouring.

Table 5. Test methods for fresh and hardened properties of concrete.

\begin{tabular}{ccc}
\hline Type & Evaluation Item & Test Method \\
\hline \multirow{3}{*}{ Concrete } & Slump $(\mathrm{mm})$ & ASTM C143 \\
& Air contents $(\%)$ & ASTM C231 \\
& Compressive strength & ASTM C873 \\
& $(\mathrm{MPa})$ & ASTM C39 \\
\hline
\end{tabular}

The compressive strength of concrete was calculated by measuring the maximum load at the target age using a 300 ton universal test machine after fabricating $\varnothing 100 \times 200 \mathrm{~mm}$ specimens in accordance with ASTM C873 [36] and ASTM C39/C39M [37]. The compressive strength of concrete was calculated as the average value obtained for three test specimens. 


\subsubsection{Maturity of Concrete}

Figure 2 shows images of the concrete curing test methods. Concrete was cured using air, chamber $\left(13^{\circ} \mathrm{C}\right)$, and cast-in-place methods. The cast-in-place method was conducted in accordance with ASTM C873/C873M [38].

This method examines the compressive strength of concrete by simulating the site slab and reproducing the temperature history of the structure. In this study, $500 \times 500 \times 210 \mathrm{~mm}^{3}$ mock-ups were fabricated, and $ø 100 \times 200 \mathrm{~mm}$ cylinder molds were embedded using sleeves. The molds were fixed to the formwork using nails to minimize deformation due to their movement during concrete pouring.

The hydration heat of concrete was measured by embedding K-type thermocouples in the center of each specimen. The maturity of concrete was calculated using Equation (1), based on the hydration heat measured in accordance with ASTM C1074 [38]:

$$
M(t)=\sum\left(T_{a}-T_{0}\right) \Delta t
$$

where $M(t)=$ the temperature-time factor at age $\mathrm{t}$, shown as degree days or degree hours; $\Delta t=\mathrm{a}$ time interval, shown as days or hours, $T_{a}=$ average concrete temperature during time interval $\Delta t$ in ${ }^{\circ} \mathrm{C}$; and $T_{o}=$ datum temperature in ${ }^{\circ} \mathrm{C}$.

\section{Results and Discussion}

\subsection{Analysis of Properties of Cement Raw Materials}

Figure 3 shows the particle size distribution of OPC, FOPC, and EPC used in this study. OPC has a mean size of $19.46 \mu \mathrm{m}$ and a fineness modulus of 1.09, while FOPC has a mean size of $16.31 \mu \mathrm{m}$ and a fineness modulus of 0.92. EPC has a mean size of $14.01 \mu \mathrm{m}$ and a fineness modulus of 0.76. EPC has the highest fineness, followed by FOPC and OPC. As for the detailed grain shape of the cement, OPC had many large particles and EPC had many fine particles, as shown in Figure 4. OPC and FOPC similarly exhibited the shape of an elliptical polyhedron for particles larger than $10 \mu \mathrm{m}$, and EPC showed fine and irregular particles. In the case of FOPC, fine and irregular particles were distributed among the elliptical polyhedrons.

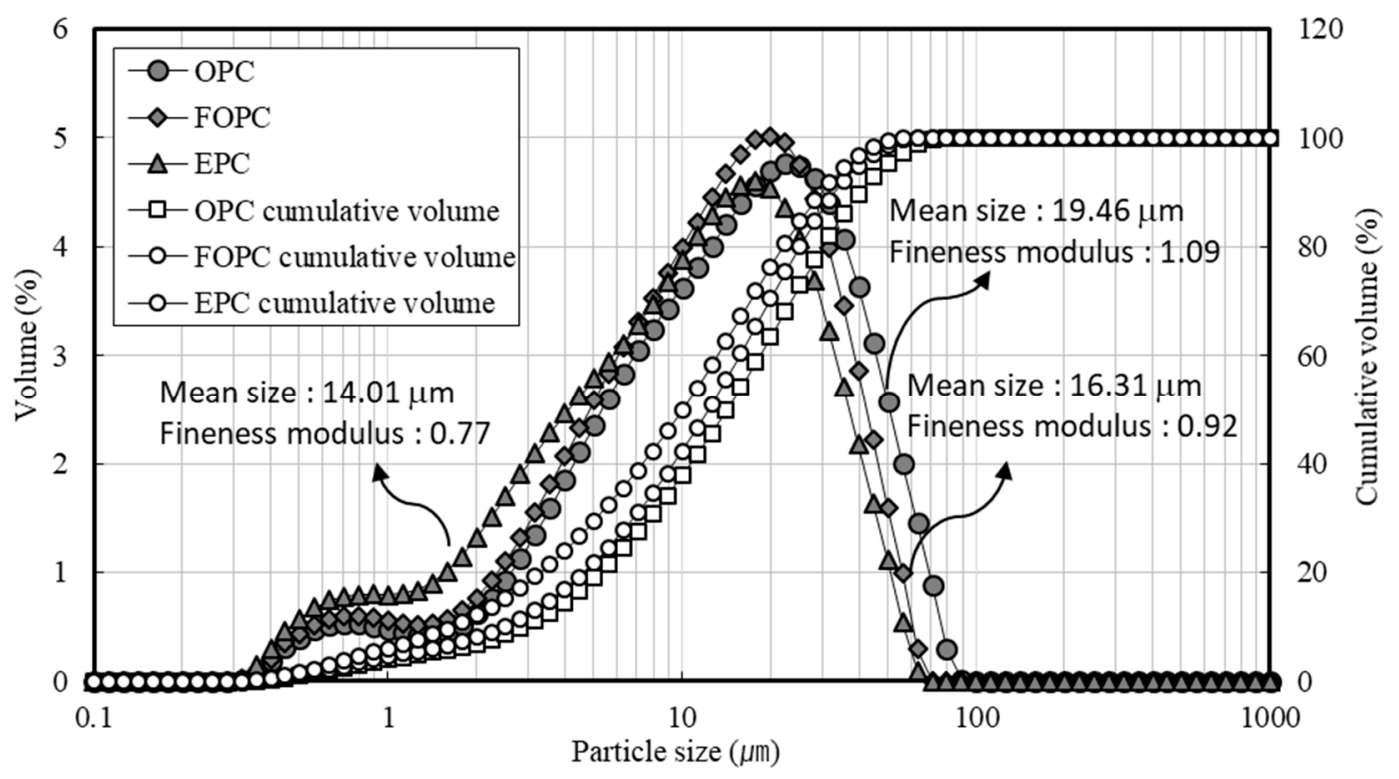

Figure 3. Particle size distribution for OPC, FOPC, and EPC. 


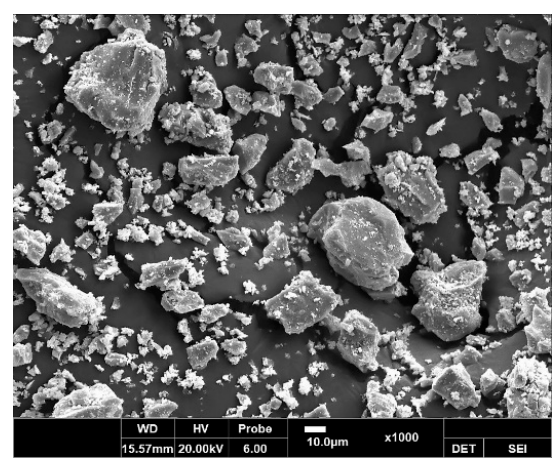

(a) OPC

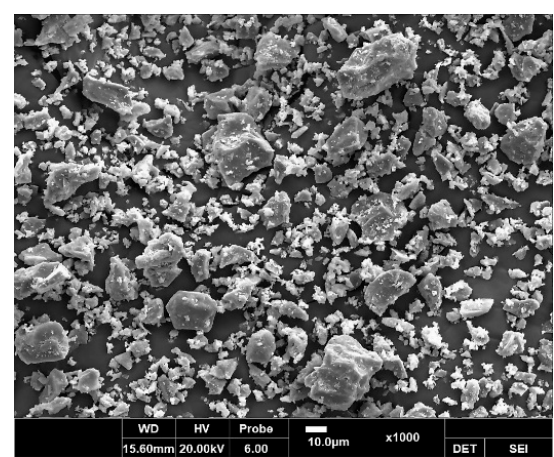

(b) FOPC

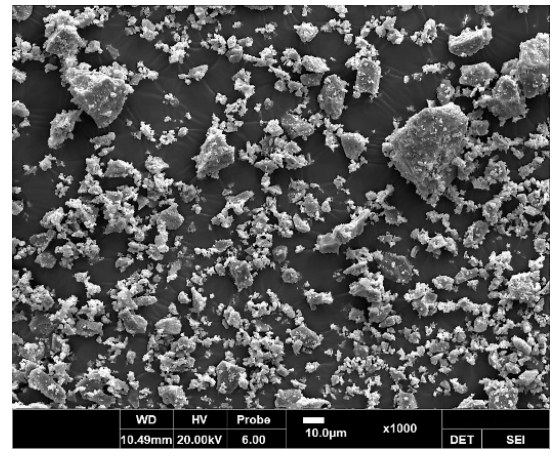

(c) EPC

Figure 4. Scanning electron microscope micrographs: (a) OPC; (b) FOPC; (c) EPC.

Figure 5 depicts $\mathrm{X}$-ray diffraction patterns pertaining to OPC, FOPC, and EPC considered in this study. It was confirmed that all cement types mainly comprise $\mathrm{C}_{3} \mathrm{~S}\left(3 \mathrm{CaO} \cdot \mathrm{SiO}_{2}\right), \mathrm{C}_{2} \mathrm{~S}\left(2 \mathrm{CaO} \cdot \mathrm{SiO}_{2}\right), \mathrm{C}_{3} \mathrm{~A}$ $\left(3 \mathrm{CaO} \cdot \mathrm{Al}_{2} \mathrm{O}_{3}\right)$, and $\mathrm{C}_{4} \mathrm{AF}\left(4 \mathrm{CaO} \cdot \mathrm{Al}_{2} \mathrm{O}_{3} \cdot \mathrm{Fe}_{2} \mathrm{O}_{3}\right)$ minerals. EPC contains more $\mathrm{C}_{3} \mathrm{~S}$ crystal peaks compared to both OPC and FOPC. The amount of $\mathrm{C}_{3} \mathrm{~S}$ calculated by Bogue's equation [39] on X-ray fluorescence analysis of OPC, FOPC, and EPC in Table 1 equaled 50.68\%, 48.72\%, and 56.47\%, respectively.

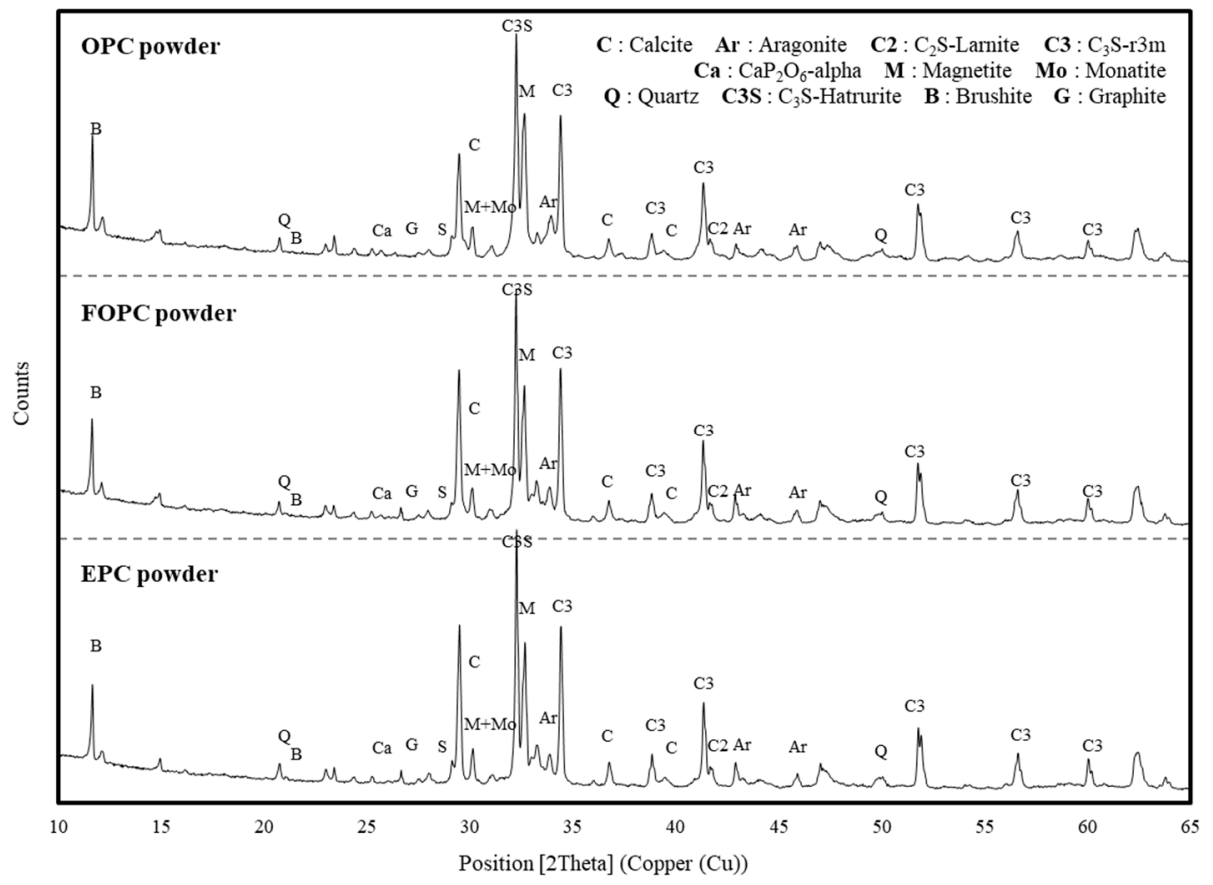

Figure 5. X-ray diffraction patterns obtained for OPC, FOPC, and EPC. 


\subsection{Fresh and Hardened Properties of Concrete}

Table 6 shows the fresh properties of concrete. All the concrete mixes met the target slump of $180 \pm 25 \mathrm{~mm}$. In the case of the FOPC mix, the slump decreased by $35 \mathrm{~mm}$, showing a significant reduction. The air content met the target of $4.5 \pm 1.5 \%$ for all the concrete mixes and a slight reduction occurred after $60 \mathrm{~min}$.

Table 6. Fresh properties of concrete.

\begin{tabular}{ccccc}
\hline \multirow{2}{*}{ Mix No. } & \multicolumn{2}{c}{ Slump $\mathbf{( m m )}$} & \multicolumn{2}{c}{ Air contents (\%) } \\
\cline { 2 - 5 } & Initial & After $\mathbf{6 0} \mathbf{~ m}$ & Initial & After $\mathbf{6 0 ~} \mathbf{~}$ \\
\hline OPC & 200 & 185 & 5.4 & 5.0 \\
FOPC & 200 & 165 & 4.4 & 4.0 \\
FOPC_TCA & 205 & 170 & 5.8 & 5.4 \\
EPC & 195 & 175 & 5.5 & 5.0 \\
\hline
\end{tabular}

Figure 6 shows early compressive strength development in concrete with time. In the case of the OPC-based concrete, it took more than $24 \mathrm{~h}$ to develop $5 \mathrm{MPa}$ at temperatures higher than $22^{\circ} \mathrm{C}$ and approximately $72 \mathrm{~h}$ at $13^{\circ} \mathrm{C}$.

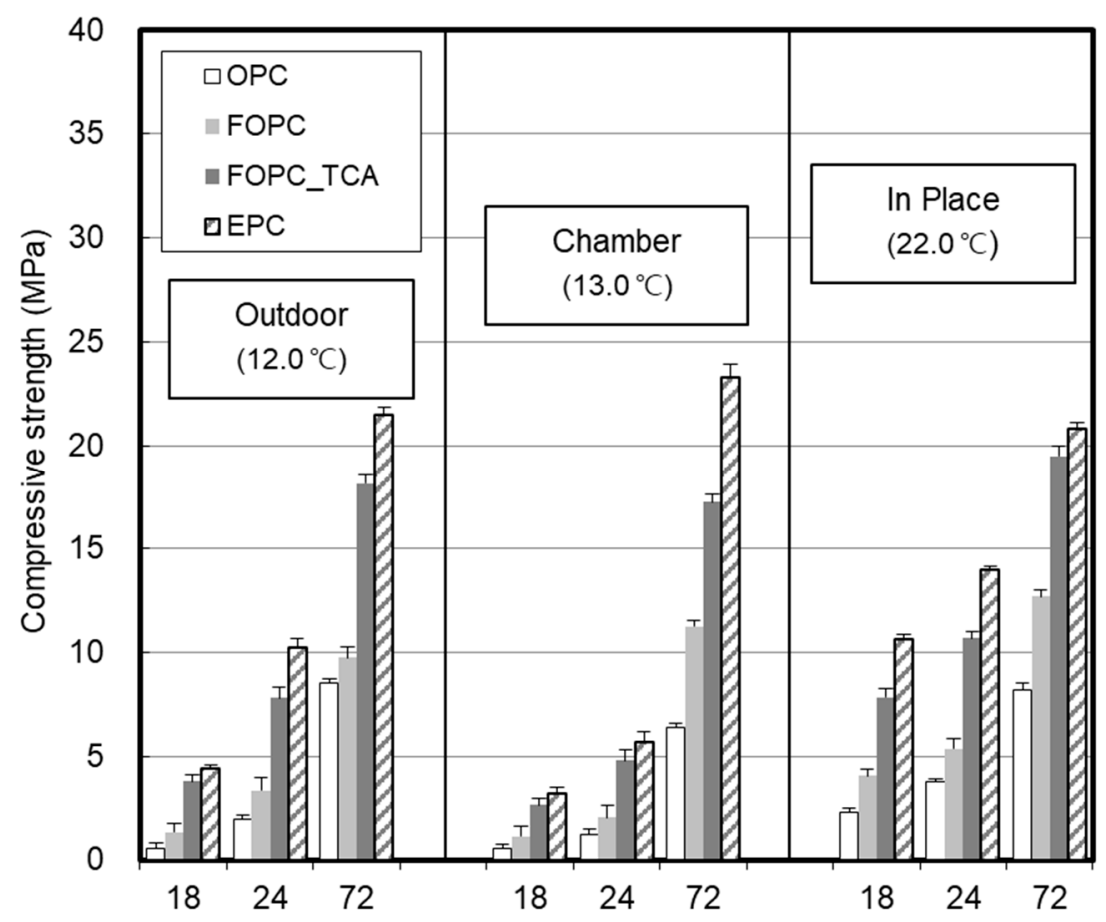

Figure 6. Early compressive strength development in concrete with time.

The FOPC-based concrete exhibited slightly higher strength compared to OPC; the strength development effect was larger at temperatures higher than $22^{\circ} \mathrm{C}$ than at lower temperatures. In the case of the concrete that used FOPC and TCA, the $5 \mathrm{MPa}$ strength development occurred within $24 \mathrm{~h}$ at $13^{\circ} \mathrm{C}$. The strength development of the concrete that used FOPC and TCA further increased as the curing temperature increased, making it possible to develop $5 \mathrm{MPa}$ within an $18 \mathrm{~h}$.

FOPC_TCA and EPC exhibited similar early strength performance within $24 \mathrm{~h}$ at low temperatures, but EPC showed higher strength after $72 \mathrm{~h}$. At temperatures higher than $22{ }^{\circ} \mathrm{C}$, FOPC_TCA and EPC could develop $5 \mathrm{MPa}$ within $18 \mathrm{~h}$. They exhibited similar strength after $72 \mathrm{~h}$. 


\subsection{Temperature History and Maturity of Concrete}

Figures 7 and 8 show the temperature history and maturity of each curing method at elapsed time points. The temperature history of concrete was maintained at $13^{\circ} \mathrm{C}$ when a constant temperature and humidity chamber was used. In the case of the outdoor conditions, diurnal temperature changes occurred and repeated temperature patterns between 8 and $28{ }^{\circ} \mathrm{C}$ were observed. As for the specimens embedded in the concrete mock-ups, the temperature increased until $30 \mathrm{~h}$ due to the hydration heat of concrete. Afterwards, repeated temperature patterns occurred in line with the outdoor temperature history.

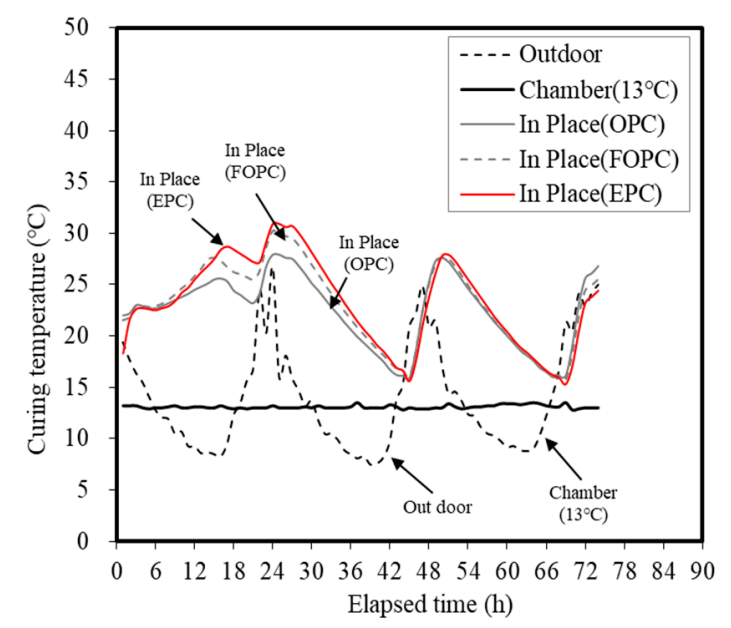

Figure 7. Temperature history of concrete for different curing methods.

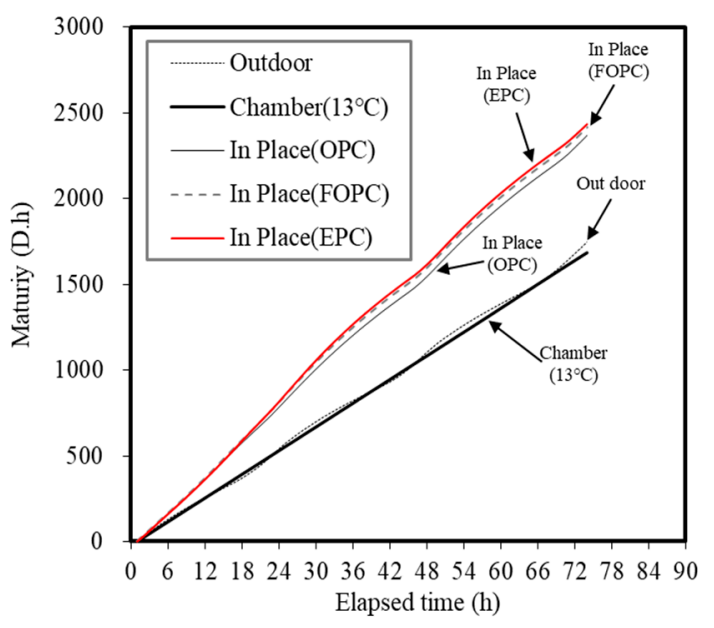

Figure 8. Concrete maturity trends for concrete when using different curing methods.

Results obtained in this study reveal that when using a small test specimen measuring $\varnothing$ $100 \times 200 \mathrm{~mm}$, temperature histories pertaining to each mixture are nearly similar in the $\pm 2{ }^{\circ} \mathrm{C}$ range of the outdoor and chamber curing temperatures. Therefore, this was suggested as the curing temperature for the outdoor and chamber samples $\left(13^{\circ} \mathrm{C}\right)$. When using the cast-in-place curing method, it was confirmed that the temperature history differs from the curing temperature corresponding to the outdoor method using a mock-up member measuring $ø 500 \times 500 \times \mathrm{H} 210 \mathrm{~mm}^{3}$. Accordingly, five temperature histories and accumulated temperatures corresponding to the outdoor, chamber $\left(13^{\circ} \mathrm{C}\right)$, and cast-in-place (OPC, FOPC, EPC) curing methods were determined.

The maturity of concrete linearly increased over time at all curing levels. Similar maturity increase patterns were observed under both outdoor and chamber $\left(13^{\circ} \mathrm{C}\right)$ conditions. The cast-in-place curing condition exhibited significantly higher values compared to the outdoor and chamber $\left(13^{\circ} \mathrm{C}\right)$ conditions, 
suggesting that the influence of the temperature history of a structure can favor strength development. Among cement types considered in this study, EPC demonstrated the highest maturity, followed by FOPC and OPC. It has been confirmed that cases affected by the temperature history of a structure exhibit higher strength development compared to small-specimen conditions. As observed, EPC- and FOPC-based concrete mixtures demonstrated greater potential for early strength development.

Figure 9 shows the comparison of the maturity and early strength of concrete. The maturity to develop a concrete compressive strength of $5 \mathrm{MPa}$ was found to be $1364 \mathrm{D} \cdot \mathrm{h}$ for OPC, $748 \mathrm{D} \cdot \mathrm{h}$ for FOPC, 504 D.h for FOPC_TCA, and 443 D.h for EPC. The reduction rate of the maturity for $5 \mathrm{MPa}$ strength development compared to OPC was 45\% when FOPC was used. FOPC_TCA (63\%) and EPC $(68 \%)$ exhibited similar reductions.

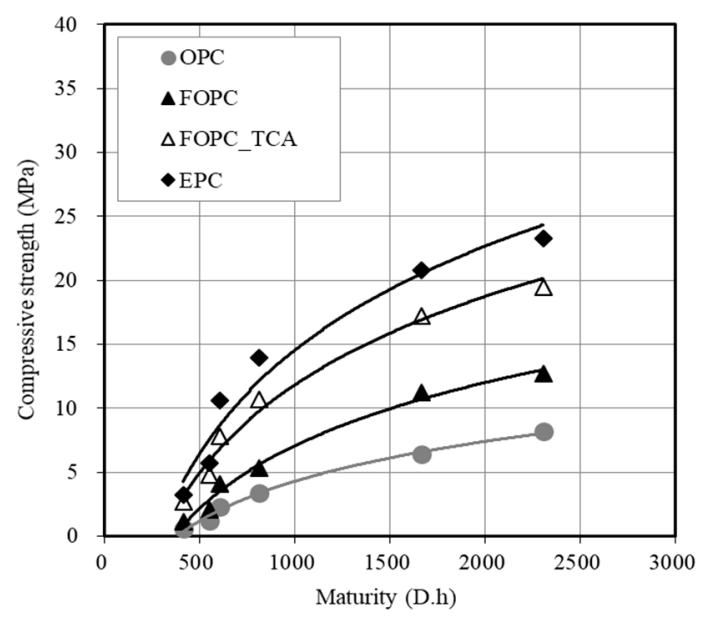

Figure 9. Comparison of maturity and early strength of concrete.

\subsection{Analysis of Factors for Early Strength Development of Concrete}

Figure 10 shows the comparison of cement fineness and the early strength of concrete. There was a linear relationship between the cement fineness and the compressive strength under the low-temperature curing condition of $13^{\circ} \mathrm{C}$. The compressive strength increased as the cement fineness increased, and the slope significantly increased after $72 \mathrm{~h}$. In the case of FOPC_TCA, the compressive strength development rate was more than twice that of FOPC and its effect was larger within $24 \mathrm{~h}$. Although FOPC_TCA was promising for securing the early compressive strength of $5 \mathrm{MPa}$, its effect was found to be slightly lower compared to EPC in terms of long-term strength.
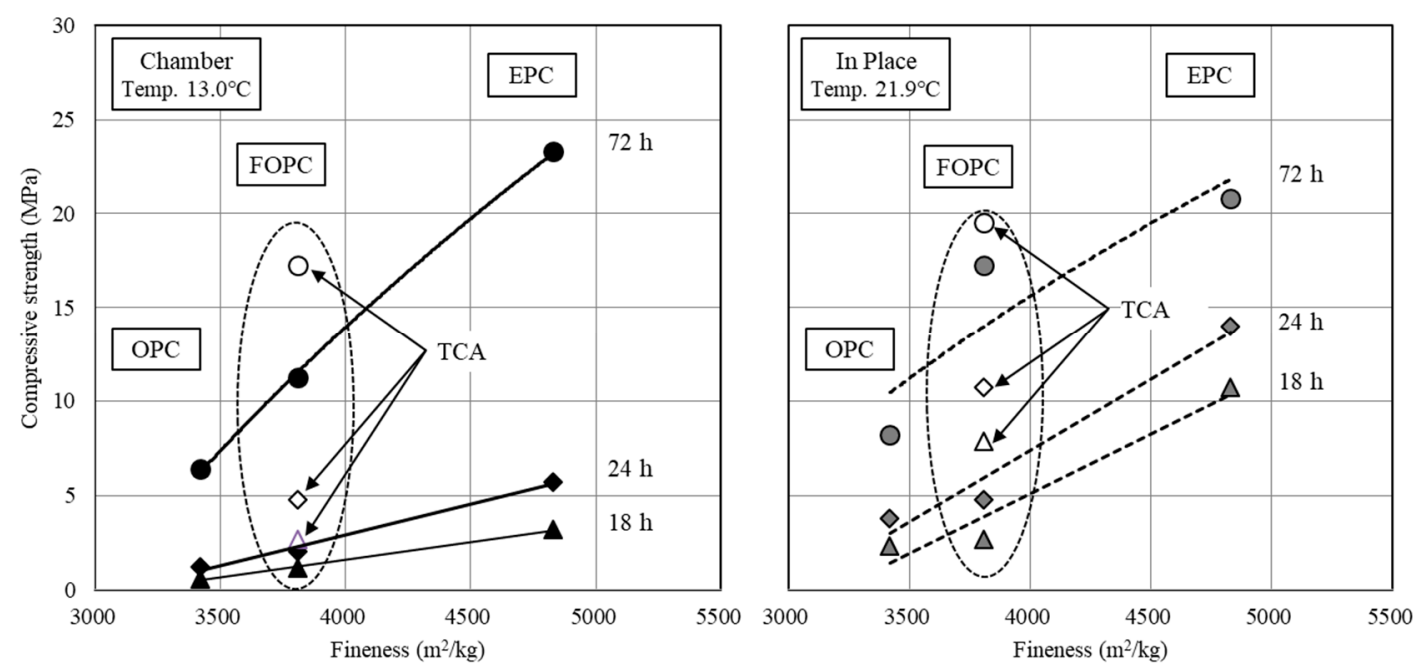

Figure 10. Comparison of cement fineness and early strength of concrete. 
At a temperature higher than $20^{\circ} \mathrm{C}$, a linear relationship with the cement fineness was observed similarly to the under $13^{\circ} \mathrm{C}$ curing condition, but the increment was larger. In addition, the compressive strength development rate significantly increased after $72 \mathrm{~h}$, resulting in smaller differences from EPC. This tendency was more noticeable when TCA was mixed. These results confirmed that the effect of increasing the fineness increased as the temperature increased, and that the effect of adding TCA was excellent at low temperatures [40-42].

This difference in fineness is a major factor influencing the difference in calories due to cement hydration. Figure 11 depicts trends concerning heat of micro-hydration observed for OPC, FOPC, and EPC. As observed, FOPC and EPC demonstrate higher values compared to OPC during the early age of up to $24 \mathrm{~h}$. Figure 12 depicts trends concerning the cumulative heat of micro-hydration observed for OPC, FOPC, and EPC. As observed, the said cumulative values for FOPC and EPC are more than twice the value corresponding to OPC.

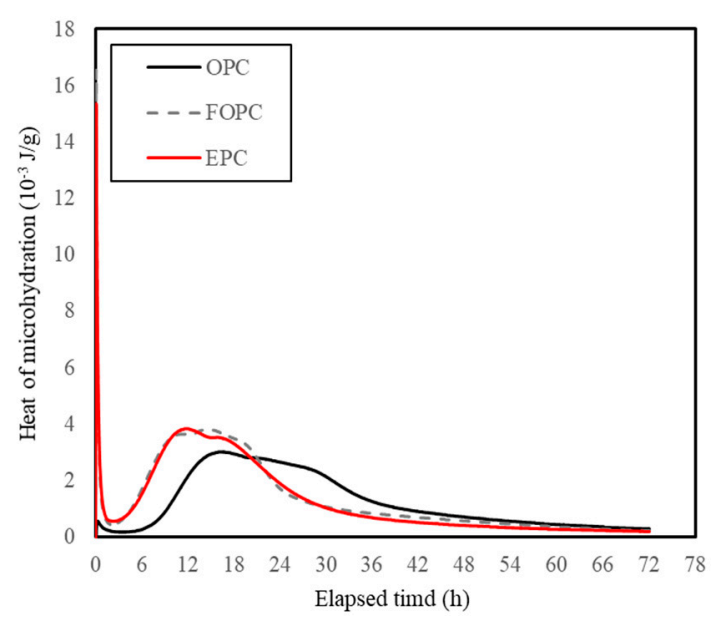

Figure 11. Heat of micro-hydration observed for OPC, FOPC, and EPC.

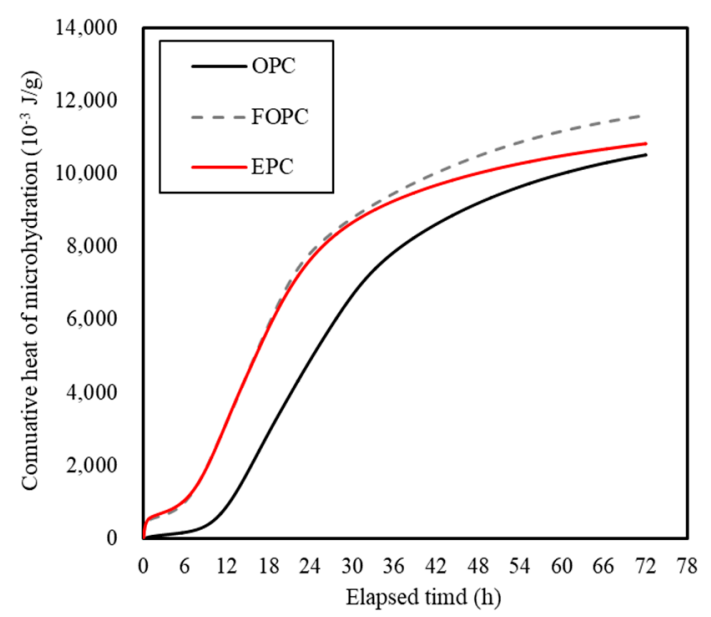

Figure 12. Cumulative heat of micro-hydration observed for OPC, FOPC, and EPC.

The $\mathrm{SO}_{3}$ content for FOPC and EPC ranged from 3\% to 4\%, which is $107-129 \%$ higher compared to OPC. These results are similar to Mohammed's report [43], which found that the compressive strength significantly increased after $48 \mathrm{~h}$ when the $\mathrm{SO}_{3}$ content ranged from $3.0 \%$ to $3.2 \%$. In addition, Lee reported that the early strength increased when the cement fineness was increased, while the $\mathrm{SO}_{3}$ content was increased to 3.1 [23-25]. In the scope of this study, we found that the effect of additionally using TCA on the early strength of concrete increases with the $\mathrm{SO}_{3}$ content of $4 \%$.

Figure 13 depicts trends concerning variation in the time required for development of $5 \mathrm{MPa}$ strength in concrete using the maturity method in accordance with the curing temperature. 


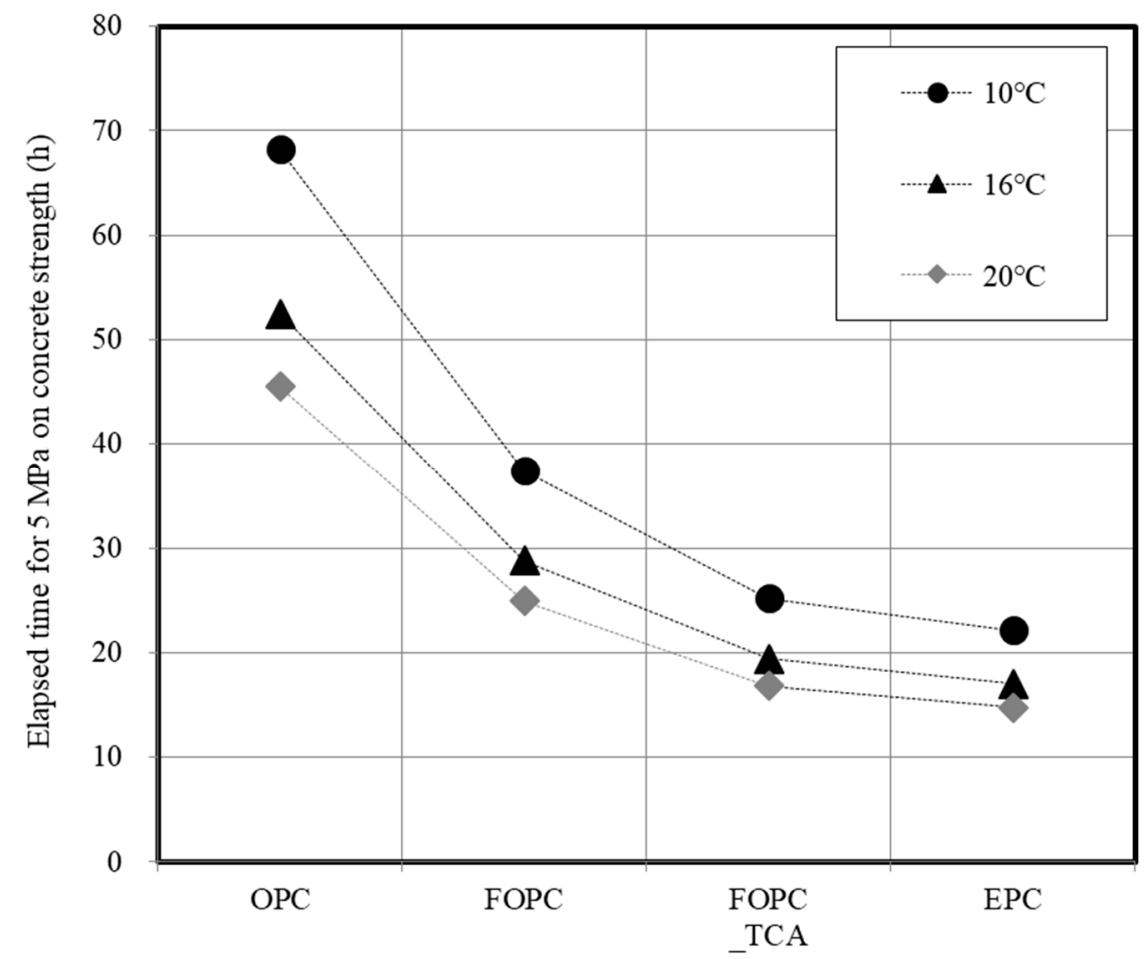

Figure 13. Elapsed time for development of $5 \mathrm{MPa}$ strength in concrete using maturity method for different curing temperatures.

In construction sites, the critical path of construction process management is the period of vertical formwork. The removal time of vertical formwork is based on ACI $\left(10{ }^{\circ} \mathrm{C}, 12 \mathrm{~h}\right)$, BS EN $\left(16{ }^{\circ} \mathrm{C}, 12 \mathrm{~h}\right)$, and Asian (Korea, Japan, 5-MPa strength development) standards [5-9]. This study refers to the Asian standard, which proposes use of a detailed value to evaluate the effect of concrete on early strength development. Through analysis of the relationship between maturity and compressive strength development, the time required for development of $5 \mathrm{MPa}$ strength was calculated in accordance with the average curing temperature.

EPC, which had the highest cement fineness and $\mathrm{SO}_{3}$ content, exhibited the shortest elapsed time for $5 \mathrm{MPa}$ development, followed by FOPC and OPC. As the temperature decreased, the time reduction effect became larger. In the case of FOPC_TCA, the elapsed time for $5 \mathrm{MPa}$ significantly decreased to a level equivalent to that of EPC.

\section{Conclusions}

In this study, the effects of the fineness and TEA-based chemical admixture on the early strength development of concrete were examined. The results are summarized as follows.

1) When evaluating the compressive strength of concrete, it was observed that the use of FOPC increases the early strength development effect at high temperatures compared to lower ones. At a curing temperature of $13{ }^{\circ} \mathrm{C}$, the development of compressive strength of FOPC_TCA was observed to increase significantly compared to FOPC. FOPC_TCA demonstrated lower overall compressive strength compared to EPC, but the overall difference observed over a $24 \mathrm{~h}$ period was negligible. With increase in curing temperature, the compressive strength development of FOPC_TCA was observed to increase significantly and tended to decrease the difference as compared to EPC.

2) The evaluation of the maturity of concrete revealed that OPC exhibited the highest maturity to develop a concrete compressive strength of $5 \mathrm{MPa}$, followed by FOPC, FOPC_TCA, and $\mathrm{EPC}$, respectively. The reduction rate of the maturity for $5 \mathrm{MPa}$ concrete strength development 
compared to OPC was $45 \%$ when FOPC was used. FOPC_TCA (63\%) and EPC (68\%) exhibited similar values.

3) There was a linear relationship between the cement fineness and the compressive strength regardless of temperature conditions, and it was found that higher temperatures had a larger influence on strength development. FOPC, with a higher fineness than OPC, showed a larger impact on strength development at high temperatures, but it is considered that the use of TCA will lead to a strength development rate equivalent to that of EPC, even at low temperatures.

4) For FOPC and EPC, the $\mathrm{SO}_{3}$ content ranged from 3\% to $4 \%$, which was $107 \%$ to $129 \%$ higher than that of OPC. As for the $\mathrm{SO}_{3} / \mathrm{Al}_{2} \mathrm{O}_{3}$ ratio, FOPC exhibited a $116.1 \%$ higher value and $\mathrm{EPC}$ a $132.2 \%$ higher value than that of OPC, indicating that they were effective in developing early strength.

The FOPC that was used in the scope of this study can contribute to improving the strength development of concrete, because its fineness and $\mathrm{SO}_{3}$ content are higher than those of OPC. In addition, the use of both FOPC and TCA can achieve performance similar to that of EPC. because it can improve early strength development, even at low temperatures. Considering construction site productivity and economic efficiency, the use of FOPC is considered to have a marked effect compared to OPC, but its economic efficiency compared to EPC needs to be examined in more detail. The results of this study are expected to be used as the basic data for the performance design of concrete mixes to shorten construction periods on construction sites.

Author Contributions: T.L., J.L., and H.C. equally contributed to the research conceptualization and all investigations performed under its purview. Resource procurement was handled by T.L. and J.L. The original draft of the manuscript was prepared by T.L. and J.L., whereas the final draft was reviewed and edited by T.L., J.L., D.-E.L., and H.C. All authors have read and agreed to the published version of the manuscript.

Funding: This work was supported by the National Research Foundation of Korea (NRF) grant funded by the Korea government (MSIT) (No. NRF-2018R1A5A1025137).

Conflicts of Interest: The authors declare no conflict of interest. The funders had no role in the design of the study; in the collection, analyses, or interpretation of data; in the writing of the manuscript, or in the decision to publish the results.

\section{References}

1. Mehta, P.; Monteiro, P. Concrete: Microstructure, Properties, and Materials, 3rd ed.; McGraw-Hill: New York, NY, USA, 2006.

2. Juilland, P.; Gallucci, E.; Flatt, R.; Scrivener, K. Dissolution theory applied to the induction period in alite hydration. Cem. Concr. Res. 2010, 40, 831-844. [CrossRef]

3. Barnes, P.; Bensted, J. Structure and Performance of Cements, 2nd ed.; CRC Press: London, UK, 2002.

4. Gartner, E.M.; Young, J.F.; Damidot, D.A.; Jawed, I. Composition of cement phases. In Structure and Performance of Cements, 2nd ed.; Bensted, J., Barnes, P., Eds.; CRC Press: London, UK, 2002; pp. 57-113.

5. ACI 347-04. Guide to Formwork for Concrete; ACI 347: New York, NY, USA, 2005.

6. Thomas Telford Services Ltd. Ceb-Fip Model Code 1990: Design Code; Thomas Telford Services Ltd.: London, UK, 1993.

7. BS EN 13670:2009. Execution of Concrete Structures; BSI: London, UK, 2010.

8. Architectural Institute of Korea. Korea Architectural Standard Specification Reinforced Concrete Work, KASS 5; Architectural Institute of Korea: Seoul Korea, 2009.

9. Architectural Institute of Japan. Japanese Architectural Standard Specification Reinforced Concrete Work JASS 5; Architectural Institute of Japan: Tokyo, Japan, 2009.

10. Lidstrom, L.; Westerberg, B. Fine ground cement in concrete-properties and prospects. ACI Mater. J. 2003, 100, 398-406.

11. Kadri, E.H.; Duval, R. Effect of ultrafine particles on heat of hydration of cement mortars. ACI Mater. J. 2002, 99, 138-142.

12. Korpa, A.; Kowald, T.; Trettin, R. Hydration behaviour, structure and morphology of hydration phases in advanced cement-based systems containing micro and nanoscale pozzolanic additives. Cem Concr Res. 2008, 38, 955-962. [CrossRef] 
13. Popescu, C.; Muntean, M.; Sharp, J. Industrial trial production of low energy belite cement. Cem. Concr. Compos. 2003, 25, 689-693. [CrossRef]

14. Winnefeld, F.; Martin, L.; Müller, C.; Lothenbach, B. Using gypsum to control hydration kinetics of CSA cements. Constr. Build. Mater. 2017, 155, 154-163. [CrossRef]

15. Gartner, E. Industrially interesting approaches to low $\mathrm{CO}_{2}$ cements. Cem. Concr. Res. 2004, 34, 1489-1498. [CrossRef]

16. Zajac, M.; Skocek, J.; Bullerjahn, F.; Haha, M. Effect of retarders on the early hydration of calcium-sulphoaluminate (CSA) type cements. Cem. Concr. Res. 2016, 84, 62-75. [CrossRef]

17. Wang, P.; Li, N.; Xu, L. Hydration evolution and compressive strength of calcium sulphoaluminate cement constantly cured over the temperature range of 0 to $80^{\circ} \mathrm{C}$. Cem. Concr. Res. 2017, 100, 203-213. [CrossRef]

18. Trauchessec, R.; Mechling, J.; Lecomte, M.; Roux, A.; Rolland, B. Hydration of ordinary Portland cement and calcium sulfoaluminate cement blends. Cem. Concr. Compos. 2015, 56, 106-114. [CrossRef]

19. Frigione, G.; Marra, S. Relationship between particle size distribution and compressive strength in Portland cement. Cem. Concr. Res. 1976, 6, 113-127. [CrossRef]

20. Osbaeck, B.; Johansen, V. Article size distribution and rate of strength development of Portland cement. J. Am. Ceram. Soc. 1989, 72, 197-201. [CrossRef]

21. Bentz, D. Blending different fineness cements to engineer the properties of cement-based materials. Mag. Concr. Res. 2010, 62, 327-338. [CrossRef]

22. Mehta, P.; Klein, A. Formation of ettringite by hydration of a system containing an anhydrous calcium sulfoaluminate. J. Am. Ceram. Soc. 1965, 48, 435-436. [CrossRef]

23. Lee, J.; Lee, T. Influences of Chemical Composition and Fineness on the Development of Concrete Strength by Curing Conditions. Materials 2019, 12, 4061. [CrossRef] [PubMed]

24. Lee, J.; Lee, T. Effects of High CaO Fly Ash and Sulfate Activator as a Finer Binder for Cementless Grouting Material. Materials 2019, 12, 3664. [CrossRef] [PubMed]

25. ASTM C150 C150M-19a. Standard Specification for Portland Cement. In American Society of Testing and Materials; ASTM: West Conshohocken, PA, USA, 2019; pp. 1-10.

26. Hewlett, P. Lea's Chemistry of Cement and Concrete, 4th ed.; Butterworth-Heinemann: London, UK, 1998; pp. 837-901.

27. Heren, Z.; Ölmez, H. The influence of ethanolamines on the hydration and mechanical strength properties of Portland cement. Cem. Concr. Res. 1996, 26, 701-705. [CrossRef]

28. Aggoun, S.; Cheikh-Zouaoui, M.; Chikh, N.; Duval, R. Effect of some admixtures on the setting time and strength evolution of cement pastes at early ages. Constr. Build. Mater. 2008, 22, 106-110. [CrossRef]

29. Lee, T.; Lee, J.; Kim, Y. Effects of admixtures and accelerators on the development of concrete strength for horizontal form removal upon curing at $10^{\circ} \mathrm{C}$. Constr. Build. Mater. 2020, 37, 1-7. [CrossRef]

30. ASTM C204. Standard test methods for fineness of hydraulic cement by air-permeability apparatus. In American Society of Testing and Materials; ASTM: West Conshohocken, PA, USA, 2018; pp. 1-11.

31. ASTM C1723-16. Standard guide for examination of hardened concrete using scanning electron microscopy. In American Society of Testing and Materials; ASTM: West Conshohocken, PA, USA, 2010; pp. 1-9.

32. ASTM C1365. Standard Test Method for Determination of the Proportion of Phases in Portland Cement and Portland-Cement Clinker Using X-Ray Powder Diffraction Analysis. In American Society of Testing and Materials; ASTM: West Conshohocken, PA, USA, 2018; pp. 1-11.

33. ASTM C1702. Standard Test Method for Measurement of Heat of Hydration of Hydraulic Cementitious Materials Using Isothermal Conduction Calorimetry. In American Society of Testing and Materials; ASTM: West Conshohocken, PA, USA, 2015; pp. 1-9.

34. ASTM C143/C143M REV, A. Standard Test Method for Slump of Hydraulic-Cement Concrete. In American Society of Testing and Materials; ASTM: West Conshohocken, PA, USA, 2015; pp. 1-4.

35. ASTM C231/C231M-17a. Standard Test Method for Air Content of Freshly Mixed Concrete by the Pressure Method. In American Society of Testing and Materials; ASTM: West Conshohocken, PA, USA, 2017; pp. 1-10.

36. ASTM C873/C873M. Standard Test Method for Compressive Strength of Concrete Cylinders Cast in Place in Cylindrical Molds. In American Society of Testing and Materials; ASTM: West Conshohocken, PA, USA, 2015; pp. 1-4.

37. ASTM C39/C39M. Standard Test Method for Compressive Strength of Cylindrical Concrete Specimens. In American Society of Testing and Materials; ASTM: West Conshohocken, PA, USA, 2018; pp. 1-8. 
38. ASTM C1074. Standard Practice for Estimating Concrete Strength by the Maturity Method. In American Society of Testing and Materials; ASTM: West Conshohocken, PA, USA, 2019; pp. 1-10.

39. Bogue, R. Calculation of the compounds in portland cement. Indus. Eng. Chem. 1929, 1, 192-197. [CrossRef]

40. Cheung, J.; Jeknavorian, A.; Roberts, L.; Silva, D. Impact of admixtures on the hydration kinetics of Portland cement. Cem. Concr. Res. 2011, 41, 1289-1309. [CrossRef]

41. Katsioti, M.; Tsakiridis, P.; Giannatos, P.; Tsibouki, Z.; Marinos, J. Characterization of various cement grinding aids and their impact on grindability and cement performance. Constr. Build. Mater. 2009, 23, 1954-1959. [CrossRef]

42. Liu, X.; Ye, Z.; Zhang, L.; Hou, P.; Cheng, X. The influence of ethanol-diisopropanolamine on the hydration and mechanical properties of Portland cement. Constr. Build. Mater. 2017, 135, 484-489. [CrossRef]

43. Mhammed, S.; Safiullahb, O. Optimization of the SO3 content of an Algerian Portland cement: Study on the effect of various amounts of gypsum on cement properties. Constr. Build. Mater. 2018, 164, 362-370. [CrossRef]

(C) 2020 by the authors. Licensee MDPI, Basel, Switzerland. This article is an open access article distributed under the terms and conditions of the Creative Commons Attribution (CC BY) license (http://creativecommons.org/licenses/by/4.0/). 